\title{
Biological Tissue-Inspired Living Self-Healing Hydrogels Based on Cadherin-Mediated Specific Cell-Cell Adhesion
}

Koji Nagahama, ${ }^{*}$ Seika Aoyama, Natsumi Ueda, Yuka Kimura, Tokitaka Katayama and Kimika Ono

Department of Nanobiochemistry, Faculty of Frontiers of Innovative Research in Science and Technology (FIRST), Konan University

7-1-20 Minatojima-Minamimachi, Kobe 650-0047, Japan

Corresponding author, E-mail: nagahama@konan-u.ac.jp

\section{Contents}

1. Experimental Section

2. Synthesis and Characterization of DBCO-Modified Branched Alginate Polymers

- Scheme S1 and S2

- Figure S1, S2, and S3

3. Formation and Analyses of CxGels

- Figure S4, S5, S6, S7, S8, S9, S10, and S11

4. Captions for Supplementary Movies

- Supplementary Movie 1, 2, 3, 4, 5, and 6

\section{Experimental Section}

\section{Materials.}

D-Mannosamine hydrochloride, 2-azidoacetic acid, acetic anhydride, pyridine, sodium alginate $\left(M_{\mathrm{w}}\right.$ : 100,000) were purchased from Sigma-Aldrich. 4-(4,6-Dimethoxy-1,3,5-triazin-2-yl)-4methylmorpholinium chloride n-hydrate (DMT-MM) was purchased from FUJIFILM Wako Chemicals. DBCO-carboxyrhodamine 110 and dibenzylcyclooctyne-PEG4-amine (DBCO-PEG4amine) were purchased from Click Chemistry Tools. Other reagents and solvents available in extrapure grade were obtained commercially and used without further purification.

\section{Synthesis of $\mathrm{Ac}_{\mathbf{4}}$ ManNAz.}

D-Mannosamine hydrochloride $(500 \mathrm{mg}, 2.3 \mathrm{mmol}$ ) was added to an aqueous solution of azidoacetic 
acid (200 $\mu \mathrm{L}, 2.4 \mathrm{mmol})$. DMT-MM (664 mg, $2.4 \mathrm{mmol}$ ) was added to this solution and the reaction mixture was stirred at $45^{\circ} \mathrm{C}$ for 2 days. The solvent was removed by evaporation to give a solid state crude reaction mixture and the $\mathrm{N}$-azidoacetyl D-mannosamine (ManNAz) product was extracted from the crude mixture by washing three times with methanol, then purified by silica gel chromatography (eluting solution: methanol/chloroform $=2 / 1, \mathrm{v} / \mathrm{v})$. Acetic anhydride $(380 \mu \mathrm{L}, 4.0 \mathrm{mmol})$ was added to a solution of ManNAz $(170 \mathrm{mg}, 0.66 \mathrm{mmol})$ in anhydrous pyridine $(5 \mathrm{~mL}, 62 \mathrm{mmol})$ and the reaction mixture was stirred overnight at room temperature under a nitrogen atmosphere. The solution was concentrated, resuspended in dichloromethane, and washed with $1 \mathrm{M}$ hydrogen chloride, saturated sodium hydrogen carbonate, and then saturated sodium chloride. The organic phase was dried using magnesium sulfate, filtered, and evaporated to give solid tetraacetylated $N$-azidoacetyl mannosamine ( $\left.\mathrm{Ac}_{4} \mathrm{ManNAz}\right) .{ }^{1} \mathrm{H}-\mathrm{NMR}\left(500 \mathrm{MHz}, \mathrm{CDCl}_{3}\right): 1.98-2.22\left(-\mathrm{OCOCH}_{3}, 12 \mathrm{H}\right), 3.81$ $(\mathrm{C} 2 \mathrm{HNHCO}-, 1 \mathrm{H}), 3.92\left(-\mathrm{COCH}_{2} \mathrm{~N}_{3}, 2 \mathrm{H}\right), 4.05-4.13\left(\mathrm{C} 3 \mathrm{H}, \mathrm{C} 4 \mathrm{H}\right.$, and $\left.\mathrm{C}^{2} \mathrm{HCH}_{2}, 4 \mathrm{H}\right), 4.27(\mathrm{C} 5 H$, 1H), $4.62(\mathrm{C} 2 H, 1 \mathrm{H}), 5.18(\mathrm{C} 1 H, 1 \mathrm{H})$. ESI-MS, calc. 430.4; found 429.08.

\section{Cell culture.}

C2C12 cells (mouse myoblast cell), HL-60 cells (human promyelocytic leukemia cell) and SH-SY5Y cells (human neuroblastoma cell) were used for preparation of CxGels. C2C12 cell was cultured in DMEM supplemented with 10\% FBS and antibiotic solution containing penicillin (100 units $\mathrm{mL}^{-1}$ ) and streptomycin $\left(100 \mu \mathrm{g} \mathrm{mL}^{-1}\right)$ and $2.0 \mathrm{mM}$ L-glutamine at $37{ }^{\circ} \mathrm{C}$ in a humidified atmosphere containing 5.0\% $\mathrm{CO}_{2}$. HL-60 cell was cultured in RPMI-1640 supplemented with 10\% FBS and antibiotic solution containing penicillin $\left(100\right.$ units $\left.\mathrm{mL}^{-1}\right)$ and streptomycin $\left(100 \mu \mathrm{g} \mathrm{mL}^{-1}\right)$ and $2.0 \mathrm{mM}$ L-glutamine at $37{ }^{\circ} \mathrm{C}$ in a humidified atmosphere containing 5.0\% $\mathrm{CO}_{2}$. SH-SY5Y cell was cultured in D-MEM/Ham's F-12 medium (FUJIFILM Wako Chemicals, Japan) supplemented with 10\% FBS, sodium pyruvate $(1 \mathrm{mM})$, non-essential amino acid $(0.1 \mathrm{mM})$, and antibiotic solution containing penicillin $\left(100\right.$ units $\left.\mathrm{mL}^{-1}\right)$ and streptomycin $\left(100 \mu \mathrm{g} \mathrm{mL} \mathrm{L}^{-1}\right)$ at $37^{\circ} \mathrm{C}$ in a humidified atmosphere containing $5.0 \% \mathrm{CO}_{2}$.

\section{Preparation and investigation of azide-modified cells.}

C2C12 cells $\left(1.0 \times 10^{5}\right)$ were seeded on a $30 \mathrm{~mm}$ glass bottom dish, then $2 \mathrm{~mL}$ of DMEM containing $\mathrm{Ac}_{4}$ ManNAz $(100 \mu \mathrm{M})$ was added and the dish was incubated at $37^{\circ} \mathrm{C}$ for 3 days. The supernatant was removed and then $2 \mathrm{~mL}$ of DMEM was freshly added to the dish. DBCO-carboxyrhodamine 110 (final concentration: $5 \mu \mathrm{M}$ ) was added to the dish and incubated at $37^{\circ} \mathrm{C}$ for 1 hour. Cells attached on the dish were washed twice with phosphate buffered saline (PBS), $1 \mathrm{~mL}$ of Live Cell Imaging Solution (Life Technologies) was added, and then the cells were observed by confocal laser scanning microscopy (CLSM, ZEISS LSM700). To perform azide-modification of cells including HL-60 and SH-SY5Y, $\mathrm{Ac}_{4} \mathrm{ManNAz}(100 \mu \mathrm{M})$ was added into the corresponding cell culture medium and the dish was incubated at $37^{\circ} \mathrm{C}$ for 3 days. To investigate mol number of azide groups introduced onto a C2C12 cell, azide-modified C2C12 cells $\left(1.1 \times 10^{4}\right.$ cells $)$ were cultured on glass bottom dish for 4 hours and reacted with different mol number of DBCO-carboxyrhodamine 110 for 1 hour, then CLSM 
measurement was performed. The fluorescence intensity per cell was quantified by Image $\mathrm{J}$ analysis using the corresponding CLSM images. Feeding mol number of DBCO-carboxyrhodamine 110 giving maximum fluorescence intensity per cell was determined from the analyses. Then, mol number of DBCO-carboxyrhodamine unreacted with the azide groups was estimated by fluorescent measurement in the supernatant. Consequently, the mol number of azide groups introduced onto a $\mathrm{C} 2 \mathrm{C} 12$ cell was estimated by the following equation:

Mol number of azide groups per $\mathrm{C} 2 \mathrm{C} 12$ cell $=$ [feeding mol number of DBCO-carboxyrhodamine giving maximum fluorescence intensity per cell $]-[$ mol number of unreacted DBCOcarboxyrhodamine] $/ 1.1 \times 10^{4}$ cells.

\section{Synthesis of branched alginate.}

4-arm PEG-NH $2(2.0 \mathrm{mg}, 0.1 \mu \mathrm{mol})$ and DMT-MM $(33.2 \mu \mathrm{g}, 0.12 \mu \mathrm{mol})$ dissolved in $2 \mathrm{~mL}$ of pure water was added to $18 \mathrm{~mL}$ of alginic acid $(100.0 \mathrm{mg}, 1 \mu \mathrm{mol})$ solution, and stirred at room temperature for 6 hours. The reaction mixture was dialyzed (MWCO: 14,000) against pure water for 2 days, then the resultant solution was freeze-dried to give white powder of branched alginate (bAlg). Molecular structure of bAlg was determined by ${ }^{1} \mathrm{H}-\mathrm{NMR}$ analysis $\left(\mathrm{D}_{2} \mathrm{O}, 85^{\circ} \mathrm{C}\right)$. The integration ratios of the anomeric protons of glucuronic acid (peak a) and mannuronic acid (peak b) in the Alg segment to the methylene protons of the PEG segment (peak c) indicated an approximate 10:1 molar ratio of Alg to 4-arm PEG in bAlg (Figure S1).

\section{Synthesis of DBCO-modified branched alginate.}

DBCO-PEG 4 -amine $(6.7 \mathrm{mg}, 12.7 \mu \mathrm{mol})$ and DMT-MM $(4.2 \mathrm{mg}, 15.3 \mu \mathrm{mol})$ dissolved in $1 \mathrm{~mL}$ of pure water was added to $19 \mathrm{~mL}$ of bAlg $(100.0 \mathrm{mg}, 0.15 \mu \mathrm{mol})$ solution, and stirred at room temperature for 24 hours. The reaction mixture was dialyzed (MWCO: 14,000) against pure water for 2 days, then the resultant solution was freeze-dried to give white powder of DBCO-modified branched alginic acid (bAlg-DBCO). Molecular structure of bAlg-DBCO was determined by ${ }^{1} \mathrm{H}-\mathrm{NMR}$ analysis $\left(\mathrm{D}_{2} \mathrm{O}, 85^{\circ} \mathrm{C}\right)$. The molecular weight $\left(M_{\mathrm{n}}\right.$ and $\left.M_{\mathrm{w}}\right)$ of bAlg-DBCO was estimated by GPC (Tosoh, HLC-8320GPC; column, TSKgel GMPWXL (7.8 mmI.D. $\times 60 \mathrm{~cm}$ ); detectors, RI; standard, PEG; eluent, $100 \mathrm{mM} \mathrm{NaNO}_{3}, 40{ }^{\circ} \mathrm{C}$ ). GPC analysis of the bAlg-DBCO showed a unimodal peak (Figure $\mathrm{S} 2$ ), indicating that no impurities were contained in the polymer preparation. Moreover, GPC analysis indicated that the molecular weight of bAlg-DBCO was slightly higher than that of bAlg. The average molecular weight of the bAlg-DBCO as estimated from GPC analyses was $1.4 \times 10^{5} \mathrm{Da}\left(M_{\mathrm{n}}\right)$ and 6.3 $\times 10^{5} \mathrm{Da}\left(M_{\mathrm{w}}\right)$. The molecular composition was estimated from the ${ }^{1} \mathrm{H}-\mathrm{NMR}$ spectrum (Figure S3) The integration ratios of the anomeric protons of glucuronic acid (peak $b$ ) and mannuronic acid (peak c) in the Alg segment to the aromatic protons of the DBCO group (peak a) showed that an average of 6 DBCO groups were introduced per bAlg molecule. 


\section{Click cross-linking reaction between azide-modified cells and bAlg-DBCO.}

Pellet of azide-modified C2C12 cells $\left(2.0 \times 10^{6}\right.$ cells $)$ was suspended with $100 \mu \mathrm{L}$ of bAlg-DBCO solution $(2 \%, \mathrm{w} / \mathrm{v})$ in HEPES buffer $(200 \mathrm{mM}, \mathrm{pH} 7.4)$ and cells were completely dispersed by gentle pipetting. The cell dispersions $\left(2.0 \times 10^{7} \mathrm{cells} / \mathrm{mL}\right)$ were added into test tube and incubated at $37^{\circ} \mathrm{C}$. Gel formation was checked by usual test tube inverting methods and rheological analyses. Normal C2C12 cells $\left(2.0 \times 10^{6}\right)$ was suspended with $100 \mu \mathrm{L}$ of bAlg-DBCO solution $(2 \%$, w/v) in HEPES buffer (200 mM, pH 7.4), and test tube inverting methods were performed as controls. Azidemodified C2C12 cells were labeled with DiI and bAlg-DBCO was labeled with FITC and crosslinking reaction was performed, then the distribution of cells and polymers in the CxGel was observed by CLSM.

Pellet of azide-modified myosatellite cells $\left(2.0 \times 10^{6}\right)$ was suspended with $100 \mu \mathrm{L}$ of bAlg-DBCO solution $(2 \%, \mathrm{w} / \mathrm{v})$ in HEPES buffer $(200 \mathrm{mM}, \mathrm{pH} 7.4)$ and by gentle pipetting cells were completely dispersed. The cell dispersions $\left(2.0 \times 10^{7}\right.$ cells $\left./ \mathrm{mL}\right)$ were spreaded onto cell culture glass bottom dish and incubated at $37^{\circ} \mathrm{C}$ to form thin $\mathrm{CxGel}$, then $\mathrm{CxGel}$ was cultured for 1 day in DMEM at $37^{\circ} \mathrm{C}$ in a humidified atmosphere containing 5.0\% $\mathrm{CO}_{2}$. As a control gel, normal myosatellite cells $\left(2.0 \times 10^{6}\right)$ was suspended with $100 \mu \mathrm{L}$ of bAlg-DBCO solution (2\%, w/v) in HEPES buffer (200 mM, pH 7.4), and the cell dispersion $\left(2.0 \times 10^{7}\right.$ cells $\left./ \mathrm{mL}\right)$ was spreaded onto cell culture glass bottom dish and cultured for 1 day in DMEM containing $45 \mathrm{mM} \mathrm{Ca}^{2+}$ ions at $37{ }^{\circ} \mathrm{C}$ in a humidified atmosphere containing $5.0 \% \mathrm{CO}_{2}$, resulting in cell-loaded thin alginate gel. Cells in CxGel and control gel was stained with DiI. A linear scratch was made on the $\mathrm{CxGel}$ and control gel using a sterile pipette tip, then after 6 and 12 hours the scratch was observed by fluorescent microscope (KEYENCE, BIOREVO BZ-9000). The wound recovered area was analyzed using Image J software and normalized to the time 0 wound. Values represent means \pm S.D $(n=3)$.

Pellet of azide-modified C2C12 cells $\left(2.0 \times 10^{6}\right)$ was suspended with $100 \mu \mathrm{L}$ of bAlg-DBCO solution $(2 \%, \mathrm{w} / \mathrm{v})$ in HEPES buffer $(200 \mathrm{mM}, \mathrm{pH} 7.4)$ and cells were completely dispersed by gentle pipetting. Rheological test of the cell dispersions $\left(2.0 \times 10^{7}\right.$ cells $\left./ \mathrm{mL}\right)$ were performed on MCR 302 rheometer (Anton Paar) using a standard steel parallel-plate geometry of $25 \mathrm{~mm}$ in diameter. Oscillatory time were performed at $37^{\circ} \mathrm{C}$, and the storage modulus $\left(G^{\prime}\right)$ and loss modulus ( $\left.G^{\prime \prime}\right)$ were recorded. The cell dispersions were cast between the lower plate and upper plate. To prevent evaporation of water and better temperature control during testing, the plates were enclosed in a chamber. Time zero was taken as the moment at which the cell dispersions were cast on the plate. The time sweep data collection was started from time zero to 15,000 seconds to monitor the gelation process. The strain was maintained at $5 \%$ and operated at $10 \mathrm{rad} / \mathrm{s}$. As a control sample, normal C2C12 cells $\left(2.0 \times 10^{6}\right)$ was also suspended with $100 \mu \mathrm{L}$ of bAlg-DBCO solution $(2 \%$, w/v) in HEPES buffer (200 mM, pH 7.4), and rheological characterization was performed. Dispersions of azide-modified cells $\left(2.0 \times 10^{7}\right.$ cells $\left./ \mathrm{mL}\right)$ such as HL-60 and SH-SY5Y, were centrifuged and the pellet was suspended with $100 \mu \mathrm{L}$ of bAlg-DBCO solution $(2 \%$, w/v) in HEPES buffer $(200 \mathrm{mM}$, pH 7.4) by gentle pipetting. Oscillatory time were performed at $37^{\circ} \mathrm{C}$, and $G$ ' and $G$ " were recorded to monitor the gelation process. The strain was maintained at $5 \%$ and operated at $10 \mathrm{rad} / \mathrm{s}$. 


\section{Characterization of CxGel.}

Pellet of azide-modified C2C12 cells $\left(2.0 \times 10^{6}\right)$ was suspended with $100 \mu \mathrm{L}$ of bAlg-DBCO solution $(2 \%, \mathrm{w} / \mathrm{v})$ in HEPES buffer $(200 \mathrm{mM}, \mathrm{pH} 7.4)$ and by gentle pipetting cells were completely dispersed. The cell dispersions $\left(2.0 \times 10^{7}\right.$ cells $\left./ \mathrm{mL}\right)$ were added into cell culture glass bottom dish and incubated at $37{ }^{\circ} \mathrm{C}$ to form $\mathrm{CxGel}$, then $\mathrm{CxGel}$ was cultured for 1 day in DMEM at $37{ }^{\circ} \mathrm{C}$ in a humidified atmosphere containing 5.0\% $\mathrm{CO}_{2}$. CxGel was treated with Live/Dead cell staining kit (PromoCell) and CLSM observation was performed. The cell viability was quantified by Image J analysis using the corresponding CLSM images. CxGels were prepared in 96-well plate and cultured for 4 days in $\mathrm{DMEM}$ at $37{ }^{\circ} \mathrm{C}$ in a humidified atmosphere containing 5.0\% $\mathrm{CO}_{2}$. After predetermined times, CxGels were carefully transferred into a new well, then $100 \mu \mathrm{L}$ of fresh DMEM and $5 \mu \mathrm{L}$ of WST-1 solution was added to the well and incubated at $37{ }^{\circ} \mathrm{C}$ for 2 hours. The gels were demolished thoroughly by vigorous pipetting, then the 96-well plate was centrifuged and the supernatant (100 $\mu \mathrm{L}$ ) was carefully sucked and poured into a new 96-well plate. Absorbance at $450 \mathrm{~nm}$ and $620 \mathrm{~nm}$ was measured by microplate reader. Values are average of three separate experiments and are expressed as mean $\pm \mathrm{SD}$. To prepare $\mathrm{C} 2 \mathrm{C} 12$ cells-encapsulating control physical gels, normal $\mathrm{C} 2 \mathrm{C} 12$ cells $\left(2.0 \times 10^{6}\right)$ were well suspended with $100 \mu \mathrm{L}$ of bAlg-DBCO solution $(2 \%, \mathrm{w} / \mathrm{v})$ in HEPES buffer in the presence of $\mathrm{Ca}$ ions $(45 \mathrm{mM})$. The cell proliferation of $\mathrm{C} 2 \mathrm{C} 12$ cells physically encapsulated in the control gels was also examined with the same WST-1 assay.

\section{Analyses of adhesive strength of CxGels.}

Pellet of azide-modified C2C12 cells $\left(1.0 \times 10^{6}\right.$ and $\left.2.0 \times 10^{6}\right)$ was suspended with $100 \mu \mathrm{L}$ of bAlgDBCO solution ( $1 \%$ and $2 \%, \mathrm{w} / \mathrm{v})$ in HEPES buffer $(200 \mathrm{mM}, \mathrm{pH} 7.4)$ and cells were completely dispersed by gentle pipetting. The cell dispersions $\left(1.0 \times 10^{7}\right.$ and $2.0 \times 10^{7}$ cells $\left./ \mathrm{mL}\right)$ were added into Transwell insert and cultured for 1 day in DMEM at $37^{\circ} \mathrm{C}$ in a humidified atmosphere containing 5.0\% $\mathrm{CO}_{2}$, resulting in $\mathrm{C} 2 \mathrm{C} 12$-based $\mathrm{CxGel}$ formation. The same $\mathrm{C} 2 \mathrm{C} 12$-based CxGel was prepared and these two CxGels were stacked in Transwell insert and incubated for $18 \mathrm{~h}$ in DMEM at $37{ }^{\circ} \mathrm{C}$ in a humidified atmosphere containing 5.0\% $\mathrm{CO}_{2}$. After that, the adhering CxGels were carefully taken out and one edge of the CxGels was fixed to inner cap of microtube by strong adhesives (GORILLA SUPER GLUE, KURE Engineering Ltd.), then the microtubes were centrifuged with changing gravity, and the gravity which adhering CxGels were dissociated to each $\mathrm{CxGel}$ at the adhesion interface was determined. Adhesive strength was estimated using the determined gravity by the equation:

Adhesive strength $[\mathrm{Pa}]=$ Weight of $\mathrm{CxGel}$ located at the lower position $[\mathrm{kg}] \times$ the gravity which adhering CxGels were dissociated to each $\mathrm{CxGel}$ at the adhesion interface $[\mathrm{g}] /$ The area of the base of $\mathrm{CxGel}\left[\mathrm{m}^{2}\right]$ 
As a control gel, normal C2C12 cells $\left(1.0 \times 10^{6}\right.$ and $\left.2.0 \times 10^{6}\right)$ was suspended with $100 \mu \mathrm{L}$ of bAlg-DBCO solution ( $2 \%$, w/v) in HEPES buffer $(200 \mathrm{mM}, \mathrm{pH} 7.4)$, and the cell dispersion $(1.0 \times$ $10^{7}$ and $2.0 \times 10^{7}$ cells $/ \mathrm{mL}$ ) was added into Transwell insert and cultured for 1 day in DMEM containing $45 \mathrm{mM} \mathrm{Ca}^{2+}$ ions at $37^{\circ} \mathrm{C}$ in a humidified atmosphere containing $5.0 \% \mathrm{CO}_{2}$, resulting in C2C12-loaded alginate gel (bAlg-DBCO/Ca ${ }^{2+} / \mathrm{N}_{3}(-) \mathrm{C} 2 \mathrm{C} 12$ gel). The same control gel was prepared and two gels were stacked in Transwell insert and incubated for $18 \mathrm{~h}$ in DMEM at $37{ }^{\circ} \mathrm{C}$ in a humidified atmosphere containing 5.0\% $\mathrm{CO}_{2}$. After that, the gels were carefully taken out and one edge of the gels was fixed to inner cap of microtube by strong adhesives, then the microtubes were centrifuged with changing gravity, and the gravity which adhering gels were dissociated to each gel at the adhesion interface was determined. Adhesive strength was estimated using the determined gravity by the above equation.

Pellet of azide-modified HL-60 cells $\left(2.0 \times 10^{6}\right)$ was suspended with $100 \mu \mathrm{L}$ of bAlg-DBCO solution $(2 \%, \mathrm{w} / \mathrm{v})$ in HEPES buffer $(200 \mathrm{mM}, \mathrm{pH} 7.4)$ and cells were completely dispersed by gentle pipetting. The cell dispersions $\left(2.0 \times 10^{7} \mathrm{cells} / \mathrm{mL}\right)$ were added into Transwell insert and cultured for 1 day in RPMI- 1640 at $37^{\circ} \mathrm{C}$ in a humidified atmosphere containing 5.0\% $\mathrm{CO}_{2}$, resulting in HL-60based $\mathrm{CxGel}$ formation. C2C12-based CxGel was prepared and HL-60-based CxGel and C2C12based $\mathrm{CxGel}$ were stacked in Transwell insert and incubated for $18 \mathrm{~h}$ in medium at $37{ }^{\circ} \mathrm{C}$ in a humidified atmosphere containing 5.0\% $\mathrm{CO}_{2}$. After that, these CxGels were carefully taken out and thier adhesion property was evaluated.

Pellet of azide-modified C2C12 cells $\left(2.0 \times 10^{6}\right)$ was suspended with $100 \mu \mathrm{L}$ of bAlg-DBCO solution $(2 \%, \mathrm{w} / \mathrm{v})$ in HEPES buffer $(200 \mathrm{mM}, \mathrm{pH} 7.4)$ and cells were completely dispersed by gentle pipetting. The cell dispersions $\left(2.0 \times 10^{7} \mathrm{cell} / \mathrm{s} / \mathrm{mL}\right)$ were added into Transwell insert and cultured for 1 day in DMEM at $37^{\circ} \mathrm{C}$ in a humidified atmosphere containing $5.0 \% \mathrm{CO}_{2}$, resulting in $\mathrm{C} 2 \mathrm{C} 12$-based $\mathrm{CxGel}$ formation. The same $\mathrm{C} 2 \mathrm{C} 12$-based $\mathrm{CxGel}$ was prepared and these two $\mathrm{CxGels}$ were stacked in Transwell insert and incubated for $18 \mathrm{~h}$ in DMEM containing $\mathrm{Ca}^{2+}$ ions $(18 \mathrm{mM}, 27 \mathrm{mM}, 36 \mathrm{mM}$, and $45 \mathrm{mM}$ ) at $37{ }^{\circ} \mathrm{C}$ in a humidified atmosphere containing 5.0\% $\mathrm{CO}_{2}$. After that, the adhering CxGels were carefully taken out and one edge of the CxGels was fixed to inner cap of microtube by strong adhesives, then the microtubes were centrifuged with changing gravity, and the gravity which adhering CxGels were dissociated to each $\mathrm{CxGel}$ at the adhesion interface was determined. Adhesive strength was estimated using the determined gravity by the above equation.

Pellet of azide-modified C2C12 cells $\left(2.0 \times 10^{6}\right)$ was suspended with $100 \mu \mathrm{L}$ of bAlg-DBCO solution $(2 \%, \mathrm{w} / \mathrm{v})$ in HEPES buffer $(200 \mathrm{mM}, \mathrm{pH} 7.4)$ and cells were completely dispersed by gentle pipetting. The cell dispersions $\left(2.0 \times 10^{7} \mathrm{cell} / \mathrm{s} / \mathrm{mL}\right)$ were added into Transwell insert and cultured for 1 day in DMEM at $37{ }^{\circ} \mathrm{C}$ in a humidified atmosphere containing $5.0 \% \mathrm{CO}_{2}$, resulting in $\mathrm{C} 2 \mathrm{C} 12$-based $\mathrm{CxGel}$ formation. $\mathrm{C} 2 \mathrm{C} 12$-based $\mathrm{CxGel}$ was reacted with various concnetrations of rhodamine-DBCO $(5,10,20$, and $30 \mu \mathrm{M})$ for 3 hours and the resultant cell surafce fluorescence was analyzed by CLSM observations. To evaluate complete inactivation of azide groups introduced in cells, the fluorescence intensity of rhodamine bound to cells was quantified by Image J software. C2C12-based CxGels were prepared and cells in the gels were reacted with rhodamine-DBCO $(30 \mu \mathrm{M})$ to inactivate the azide 
groups. The CxGel was carefully washed with large amount of PBS three times. The same C2C12based $\mathrm{N}_{3}$-inactivated $\mathrm{CxGel}$ was prepared and these two $\mathrm{CxGels}$ were stacked in Transwell insert and incubated for $18 \mathrm{~h}$ in DMEM containing $\mathrm{Ca}^{2+}$ ions $(45 \mathrm{mM})$ at $37^{\circ} \mathrm{C}$ in a humidified atmosphere containing $5.0 \% \mathrm{CO}_{2}$. After that, these CxGels were carefully taken out and their adhesion property was evaluated.

Pellet of azide-modified C2C12 cells $\left(2.0 \times 10^{6}\right)$ was suspended with $100 \mu \mathrm{L}$ of bAlg-DBCO solution $(2 \%, \mathrm{w} / \mathrm{v})$ in HEPES buffer $(200 \mathrm{mM}, \mathrm{pH} 7.4)$ and cells were completely dispersed by gentle pipetting. The cell dispersions $\left(2.0 \times 10^{7} \mathrm{cells} / \mathrm{mL}\right)$ were added into Transwell insert and cultured for 1 day in DMEM at $37^{\circ} \mathrm{C}$ in a humidified atmosphere containing $5.0 \% \mathrm{CO}_{2}$, resulting in $\mathrm{C} 2 \mathrm{C} 12$-based $\mathrm{CxGel}$ formation. The same $\mathrm{C} 2 \mathrm{C} 12$-based $\mathrm{CxGel}$ was prepared and these two $\mathrm{CxGels}$ were stacked in Transwell insert and incubated for $18 \mathrm{~h}$ in DMEM containing gelatin $(0.5 \%, \mathrm{w} / \mathrm{v})$ and $\mathrm{Ca}^{2+}$ ions $(45 \mathrm{mM})$ at $37^{\circ} \mathrm{C}$ in a humidified atmosphere containing $5.0 \% \mathrm{CO}_{2}$. After that, the adhering CxGels were carefully taken out and one edge of the CxGels was fixed to inner cap of microtube by strong adhesives, then the microtubes were centrifuged with changing gravity, and the gravity which adhering CxGels were dissociated to each $\mathrm{CxGel}$ at the adhesion interface was determined. Adhesive strength was estimated using the determined gravity by the above equation.

Azide-modified $\mathrm{C} 2 \mathrm{C} 12$ cells $\left(2.0 \times 10^{6}\right)$ was labeled with $\mathrm{DiO}$ (green) and their pellet was suspended with $100 \mu \mathrm{L}$ of bAlg-DBCO solution (2\%, w/v) in HEPES buffer (200 mM, pH 7.4) and cells were completely dispersed by gentle pipetting. The cell dispersions $\left(2.0 \times 10^{7} \mathrm{cells} / \mathrm{mL}\right)$ were added into Transwell insert and cultured for 1 day in DMEM at $37^{\circ} \mathrm{C}$ in a humidified atmosphere containing 5.0\% $\mathrm{CO}_{2}$, resulting in $\mathrm{C} 2 \mathrm{C} 12$-based $\mathrm{CxGel}$ formation. Azide-modified $\mathrm{C} 2 \mathrm{C} 12$ cells $(2.0$ $\times 10^{6}$ ) was labeled with CellBrite ${ }^{\circledR}$ Orange and their pellet was suspended with $100 \mu \mathrm{L}$ of bAlgDBCO solution ( $2 \%$, w/v) in HEPES buffer $(200 \mathrm{mM}, \mathrm{pH} 7.4)$ and cells were completely dispersed by gentle pipetting. The cell dispersions $\left(2.0 \times 10^{7}\right.$ cells $\left./ \mathrm{mL}\right)$ were added into Transwell insert and cultured for 1 day in DMEM at $37^{\circ} \mathrm{C}$ in a humidified atmosphere containing $5.0 \% \mathrm{CO}_{2}$, resulting in C2C12-based CxGel formation. DiO-labeled C2C12-based CxGel and CellBrite ${ }^{\circledR}$ Orange-labeled C2C12-based CxGel were stacked in Transwell insert and incubated for $18 \mathrm{~h}$ in DMEM containing $\mathrm{Ca}^{2+}$ ions $(45 \mathrm{mM})$ at $37{ }^{\circ} \mathrm{C}$ in a humidified atmosphere containing $5.0 \% \mathrm{CO}_{2}$. After that, the adhering CxGels were carefully taken out and fixed by formalin treatment and immunostaining was performed using Alexa Fluor ${ }^{\circledR}$ 350-labeled anti-N-cadherin antibody, then CLSM observation was performed.

\section{Investigation of self-healing ability of $\mathrm{CxGels.}$}

Pellet of azide-modified C2C12 cells $\left(2.0 \times 10^{6}\right)$ was suspended with $100 \mu \mathrm{L}$ of bAlg-DBCO solution $(2 \%, \mathrm{w} / \mathrm{v})$ in HEPES buffer $(200 \mathrm{mM}, \mathrm{pH} 7.4)$ and cells were completely dispersed by gentle pipetting. The cell dispersions $\left(2.0 \times 10^{7}\right.$ cells $\left./ \mathrm{mL}\right)$ were added into Transwell insert and cultured for 1 day in $\mathrm{DMEM}$ at $37^{\circ} \mathrm{C}$ in a humidified atmosphere containing $5.0 \% \mathrm{CO}_{2}$, resulting in $\mathrm{C} 2 \mathrm{C} 12$-based $\mathrm{CxGel}$ formation. The $\mathrm{CxGel}$ was taken out and cut into samll pieces on cell culture dish and these pieces were stacked in Transwell insert and incubated for $18 \mathrm{~h}$ in DMEM containing $\mathrm{Ca}^{2+}$ ions (45 mM) at $37^{\circ} \mathrm{C}$ in a humidified atmosphere containing 5.0\% $\mathrm{CO}_{2}$. After that, the self-healing CxGels were 
carefully taken out and one edge of the $\mathrm{CxGel}$ was fixed to inner cap of microtube by strong adhesives, then the microtubes were centrifuged with changing gravity, and the gravity which adhering CxGels were dissociated to each piece at the adhesion interface was determined. Adhesive strength was estimated using the determined gravity by the above equation. 
2. Synthesis and Characterization of DBCO-Modified Branched Alginate Polymers

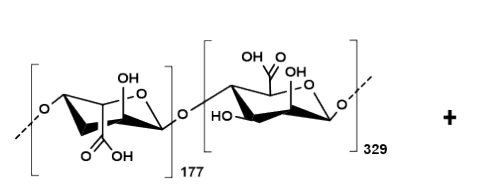

Alginate

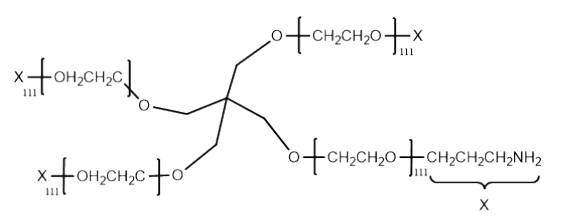

4-arm PEG- $\mathrm{NH}_{2}$
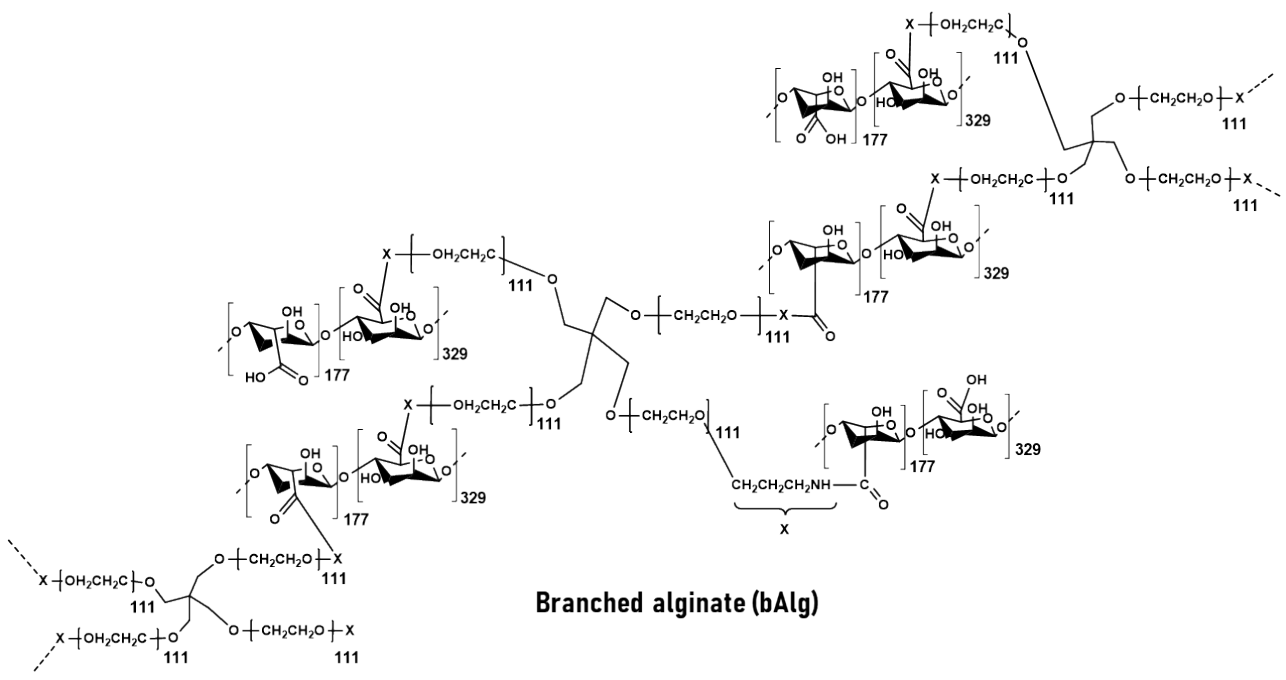

Branched alginate (bAlg)

Scheme S1. Synthesis of branched alginate (bAlg). 


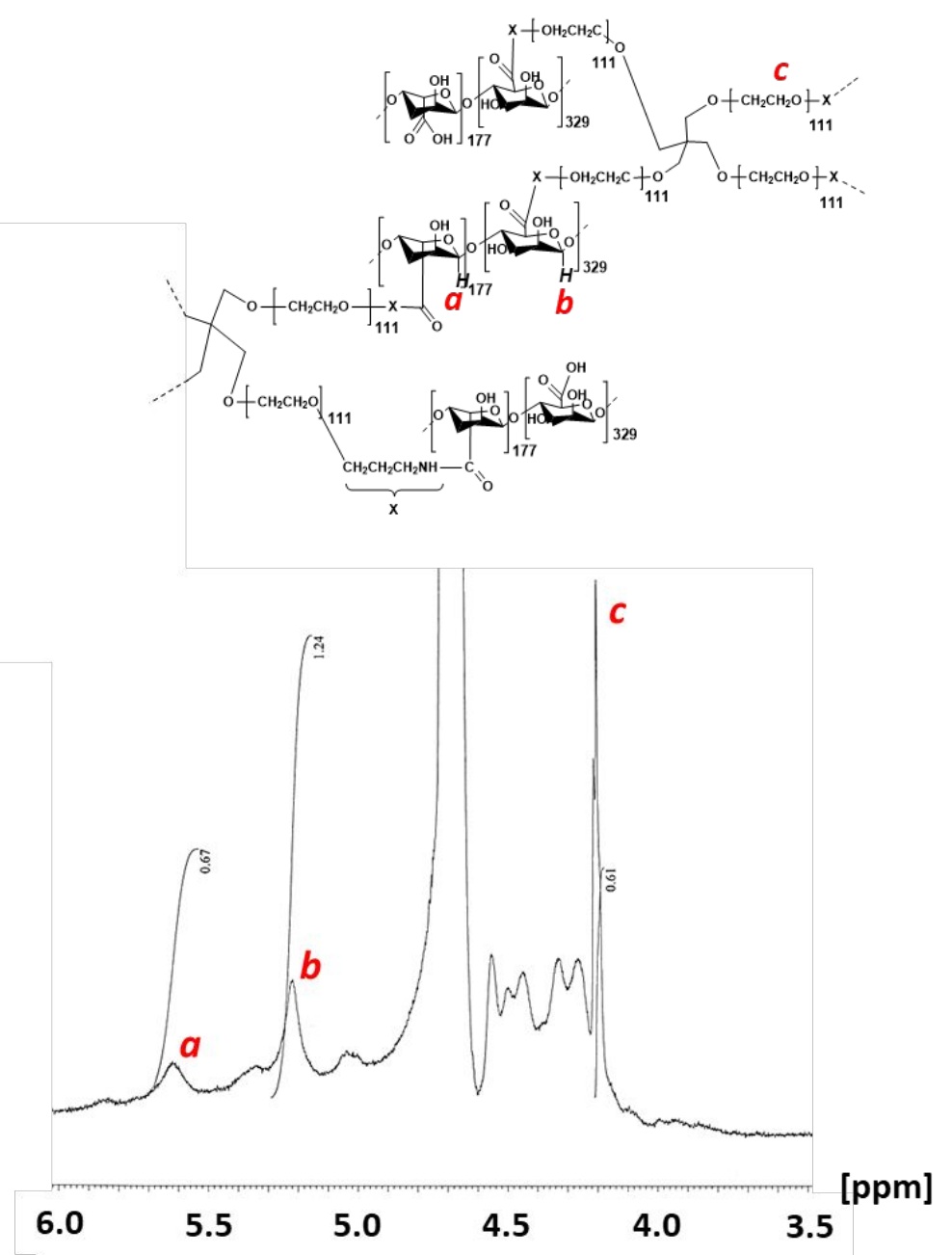

Figure S1. ${ }^{1} \mathrm{H}-\mathrm{NMR}$ spectrum of the branched alginate (bAlg). 

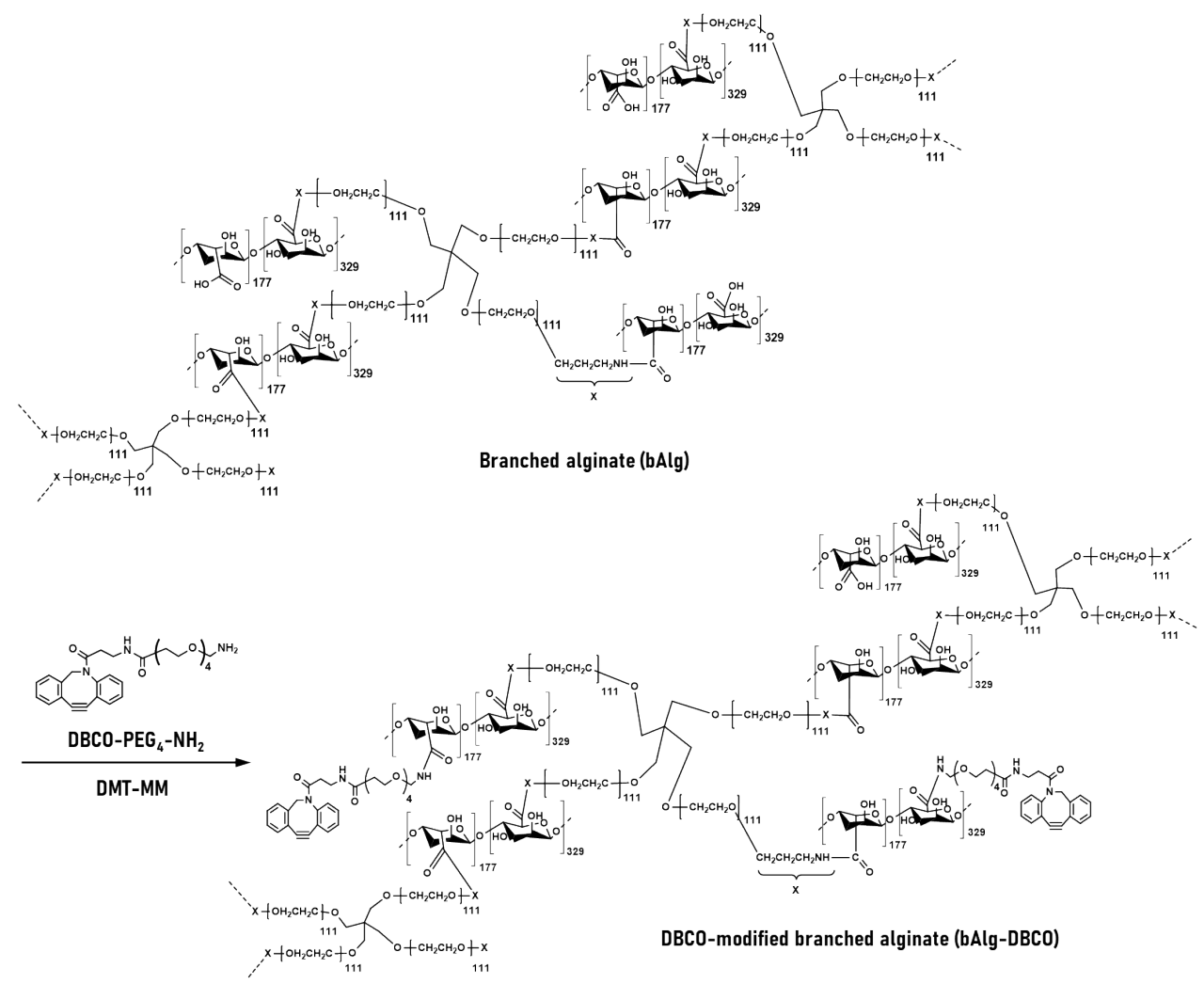

Scheme S2. Synthesis of DBCO-modified branched alginate (bAlg-DBCO).

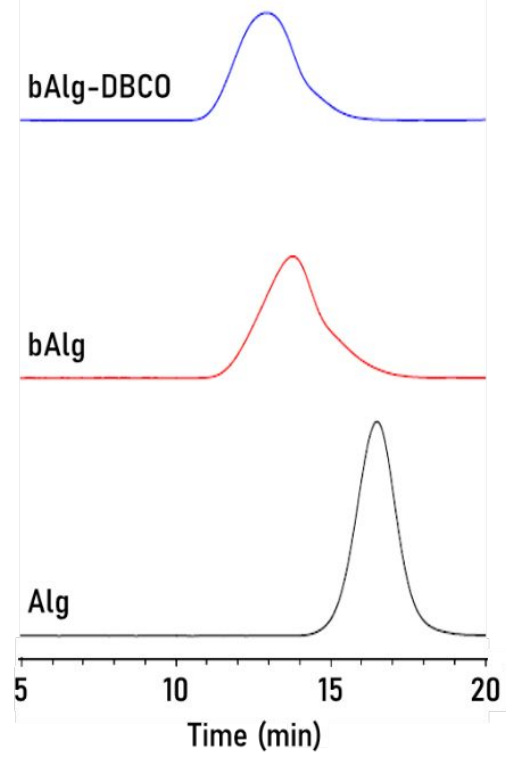

Figure S2. GPC chart of Alg, bAlg and bAlg-DBCO. Column, TSKgel GMPWXL (7.8 mmI.D. $\times 60$ $\mathrm{cm}$ ); detectors, RI; standard, PEG; eluent, $100 \mathrm{mM} \mathrm{NaNO}_{3}, 40^{\circ} \mathrm{C}$. 


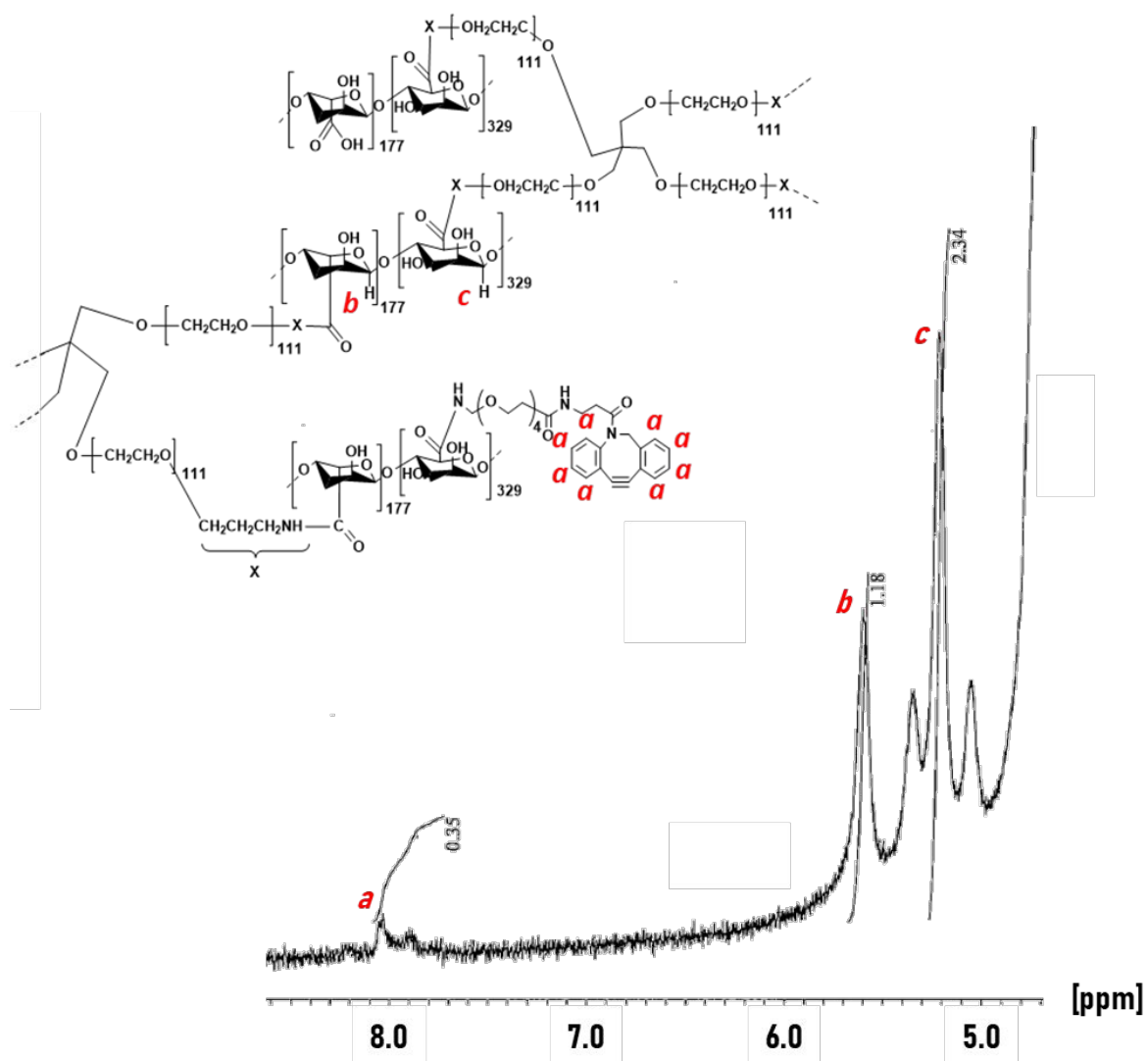

Figure S3. ${ }^{1} \mathrm{H}-\mathrm{NMR}$ spectrum of DBCO-modified branched alginate (bAlg-DBCO).

\section{Formation and Analyses of CxGels}

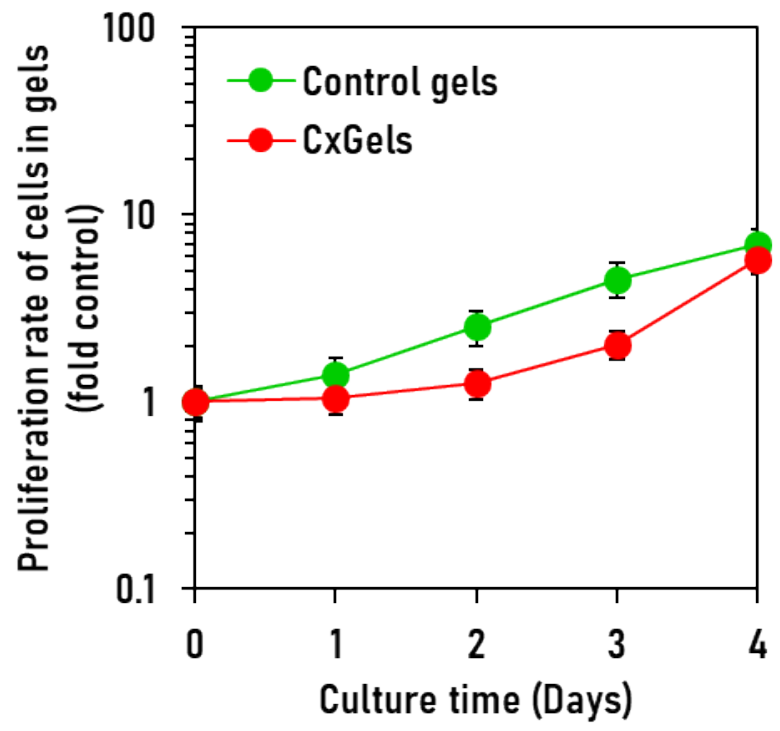

Figure S4. Proliferation of $\mathrm{C} 2 \mathrm{C} 12$ cells in CxGels and control gels cultured in the medium for 4 days. 

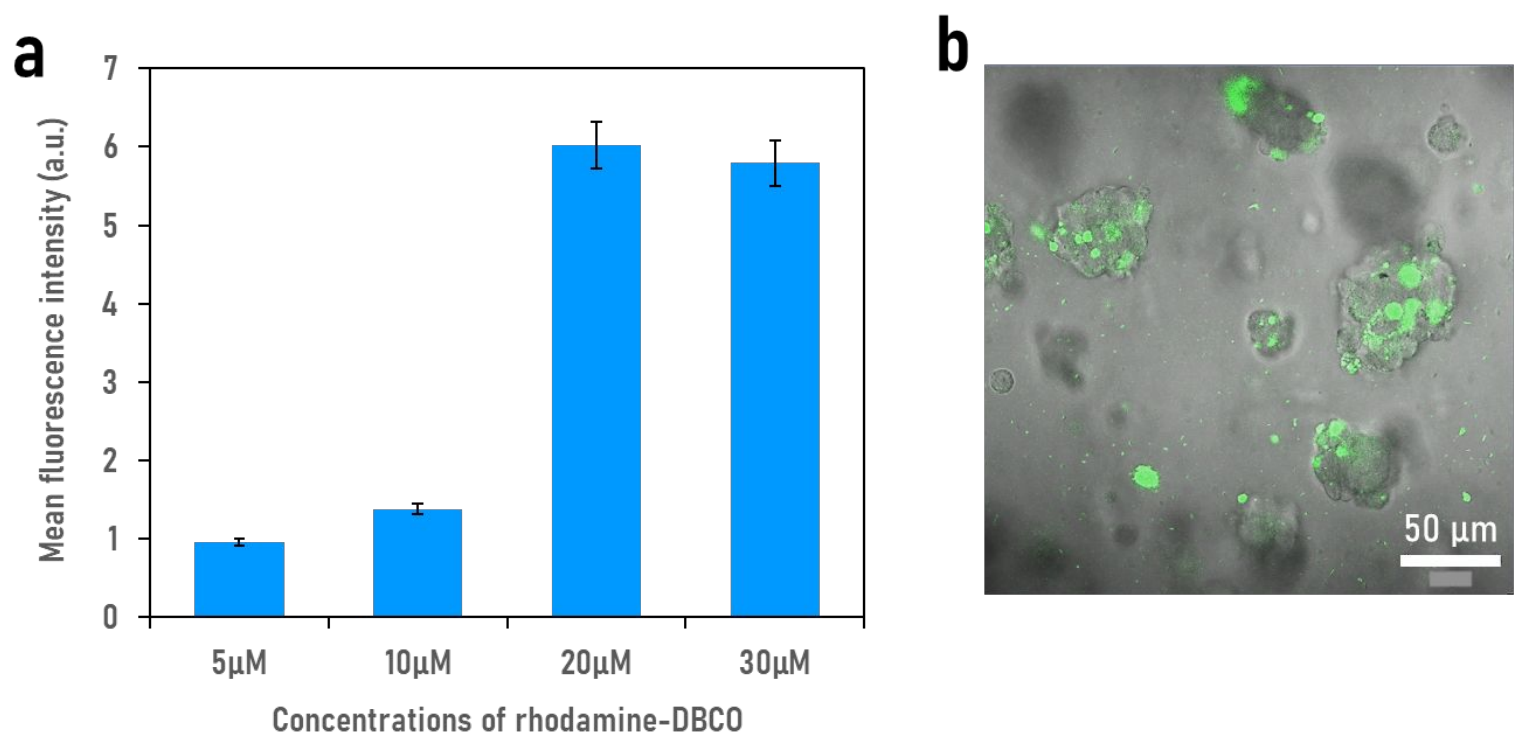

Figure S5. (b) Relative fluorescence intensity of $\mathrm{C} 2 \mathrm{C} 12$ cells in $\mathrm{CxGels}$ after treatments with various concentrations of DBCO-rhodamine. (b) CLSM images of $\mathrm{C} 2 \mathrm{C} 12$ cells in CxGels treated with DBCO-rhodamine $(30 \mu \mathrm{M})$.

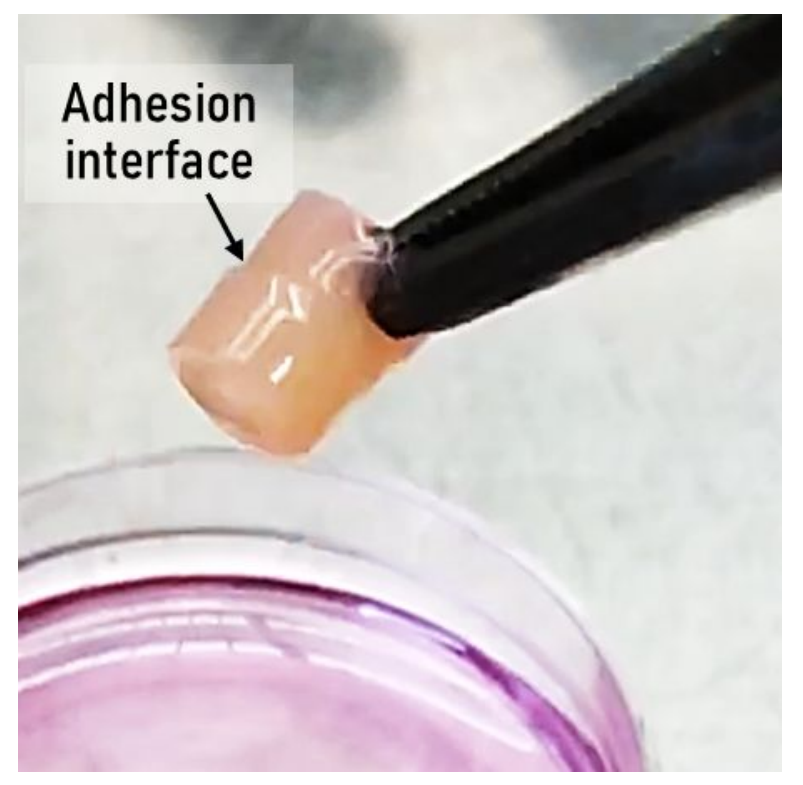

Figure S6. Photograph of adhesion test of azide-inactivated C2C12-based CxGels. 


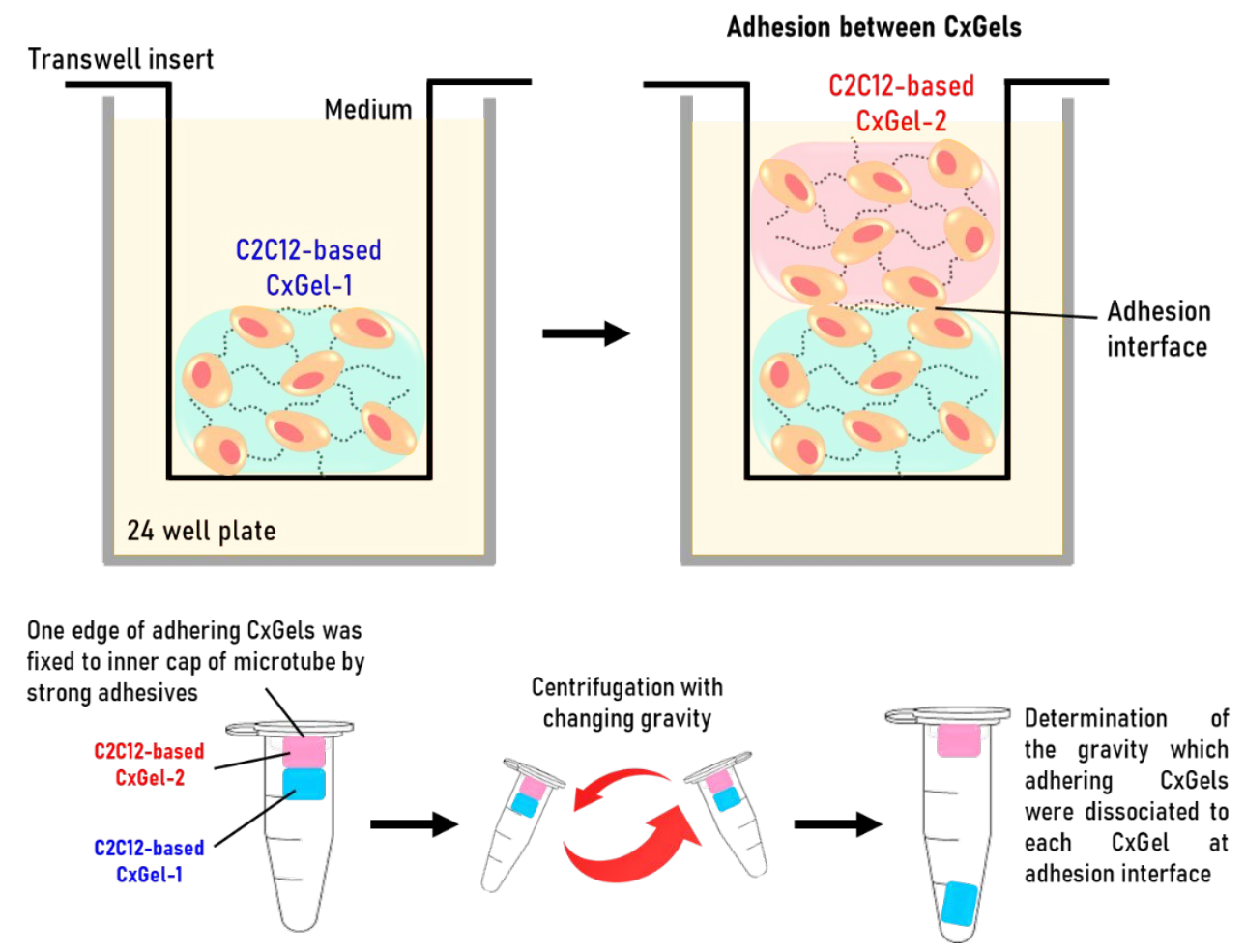

Figure S7. Procedures to determine adhesive strength of CxGels.

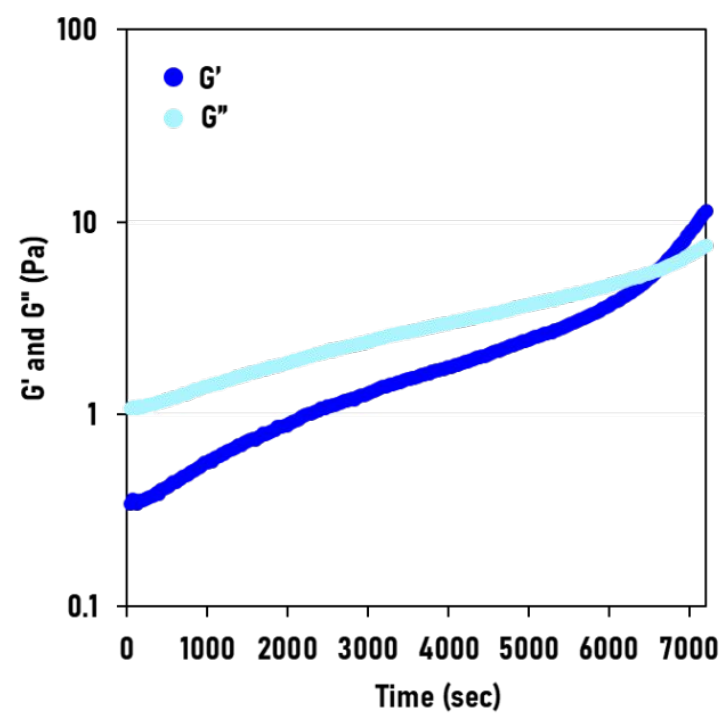

Figure S8. Gelation kinetics determined through oscillatory time sweep of CxGel prepared with $\mathrm{N}_{3}[+]$ HL-60 $\left(2.0 \times 10^{7}\right.$ cells $\left./ \mathrm{mL}\right)$ and $2 \%$ bAlg-DBCO solution at $37^{\circ} \mathrm{C}$ under constant strain $(5 \%)$ and frequency $(10 \mathrm{rad} / \mathrm{s})$. 


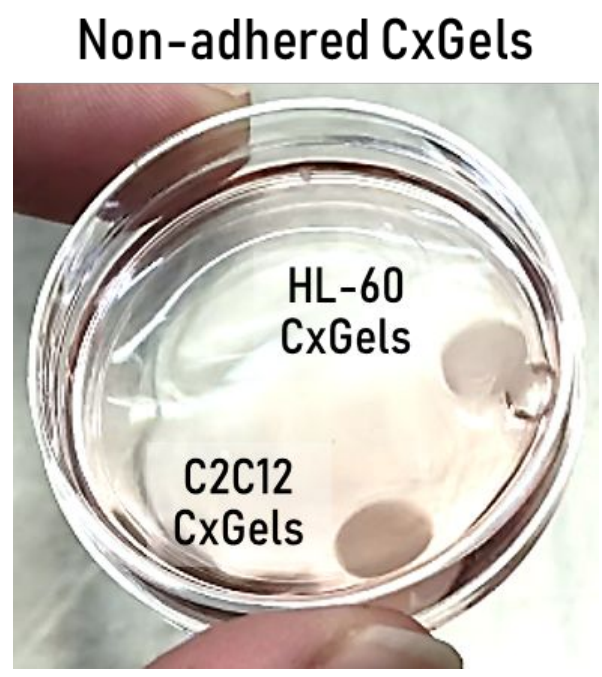

Figure S9. Photographs of non-adhering C2C12-based CxGel and HL-60-based CxGel.
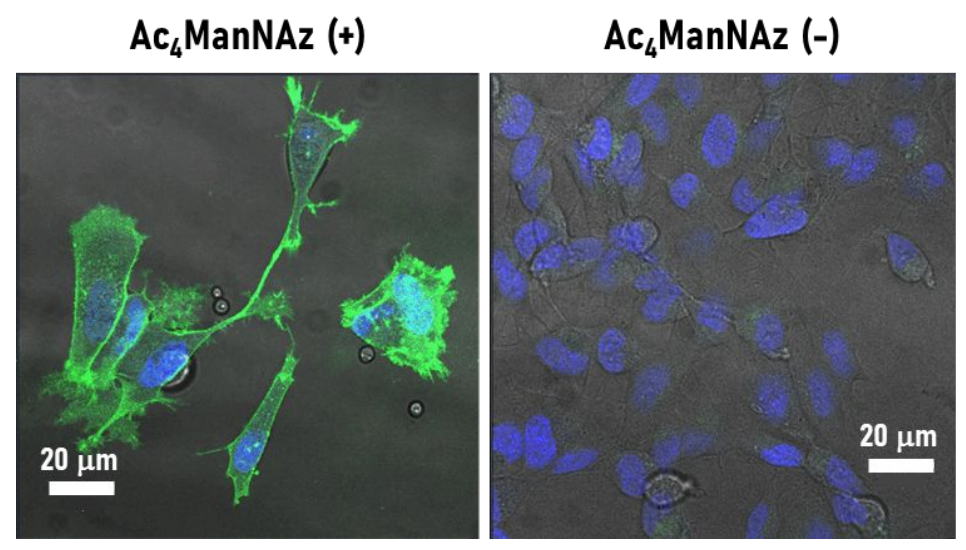

Figure S10. CLSM images of SH-SY5Y cells cultured for 3 days in the presence or absence of $\mathrm{Ac}_{4} \mathrm{ManNAz}$, then reacted with rhodamine-DBCO. 


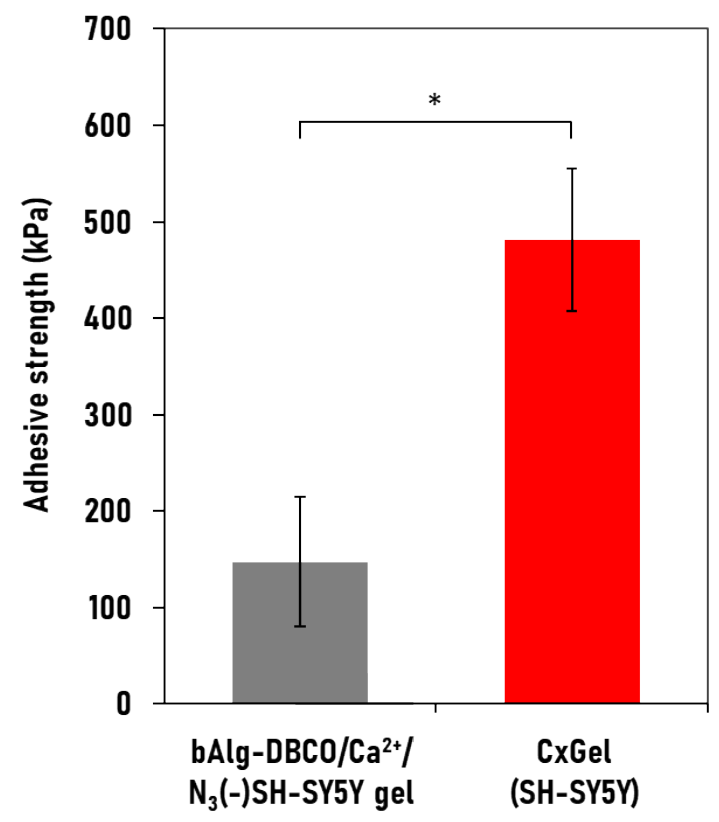

Figure S11. Adhesive strength of SH-SY5Y-based CxGel and control gel (bAlg$\mathrm{DBCO} / \mathrm{Ca}^{2+} / \mathrm{N}_{3}[-] \mathrm{SH}-\mathrm{SY} 5 Y$ gel). The values represent mean $\pm \mathrm{SD}$ of three independent experiments. $* P<0.05$.

\section{Captions for Supplementary Movies}

Movie S1: Adhesion performance of C2C12-based CxGel and C2C12-based CxGel.

Movie S2: Adhesion performance of azide-inactivate $\mathrm{C} 2 \mathrm{C} 12$-based $\mathrm{CxGel}$ and azide-inactivate C2C12-based CxGel.

Movie S3: No adhesion performance of C2C12-based CxGel and HL-60-based CxGel.

Movie S4: No adhesion performance of $\mathrm{C} 2 \mathrm{C} 12$-based $\mathrm{CxGel}$ and $\mathrm{C} 2 \mathrm{C} 12$-based $\mathrm{CxGel}$ in the presence of $27 \mathrm{mM} \mathrm{Ca}^{2+}$ ions.

Movie S5: Adhesion performance of $\mathrm{C} 2 \mathrm{C} 12$-based $\mathrm{CxGel}$ and $\mathrm{C} 2 \mathrm{C} 12$-based $\mathrm{CxGel}$ in the presence of $36 \mathrm{mM} \mathrm{Ca}^{2+}$ ions.

Movie S6: Adhesion performance of $\mathrm{C} 2 \mathrm{C} 12$-based $\mathrm{CxGel}$ and $\mathrm{C} 2 \mathrm{C} 12$-based $\mathrm{CxGel}$ in the presence of $45 \mathrm{mM} \mathrm{Ca}^{2+}$ ions. 